\title{
Comparision of Voltage Stress Across the MOSFET Switch of a Flyback Converter with Various Snubbers
}

\author{
Soumya \\ Dept. of EEE \\ BMSCE \\ Bengaluru, India
}

\author{
A.N Nagashree \\ Dept. of EEE \\ BMSCE \\ Bengaluru, India
}

\author{
R.S Geetha \\ Dept. of EEE \\ BMSCE \\ Bengaluru, India
}

\begin{abstract}
A Flyback converter is a simple switch-mode power supply that can be used to generate a DC output from either an AC or DC input. The converter switch is the most critical part of any converter. The voltage stress across the switch is a major issue as the high voltage spikes occur due to interaction between its output capacitance and the leakage inductance of the transformer. These spikes can be reduced with various snubbers like conventional tertiary winding, Resistor Capacitor and Diode(RCD) snubber, energy regenerative snubber and an active clamp snubber. This paper aims to analyze and compare the voltage stress across the MOSFET switch of Flyback converter with various snubber circuits.
\end{abstract}

Keywords:- Active clamp snubber; Energy regenerative snubber; Flyback converter; RCD snubber; Tertiary winding reset.

\section{INTRODUCTION}

Flyback converter is the simplest isolated DC-DC converter topology widely used in low power applications due to its cost effectiveness and electrical isolation characteristics [1]. Its main power circuit comprises of a MOSFET as a switch, a transformer, an output diode and an output filter capacitor. The transformer winding polarities of flyback converter are designed in such a way that when the current passes through only one winding at a time [1].

The application of transformer is an efficient method to provide the electrical isolation between input and output of a dc-dc converter [1]. A steady current builds-up in every cycle, within the magnetizing inductance of the transformer. This steady buildup of current results in saturation of the transformer core [1]. Therefore, it needs to be reset always for each pulse and this problem can be solved by using a tertiary winding [1]. In Flyback converters, switching voltage spikes appears across the converter switches during its turn off time that can be reduced with the addition of snubber circuit [1]. A snubber normally comprises of a capacitor that is greater than the output capacitance of the switch that helps to discharge the output capacitor. A snubber circuit also serves to reduce turn-off switching losses [1].
The main focus in this paper is to compare voltage stress on the converter switch using different snubber circuits. This paper is organized as follows: Section I consists of an introduction, Section II explains the working of Flyback converter, Section III discusses about various types of snubber and its working, Section IV discusses the simulation results of the Flyback converter with various types of snubbers.

\section{FLYBACK CONVERTER}

Flyback converter is the most popular DC-DC converter topology for the applications involving $150 \mathrm{~W}$ of power or less as it is simple and cost effective. The basic topology of a Flyback circuit is shown in Fig. 1.

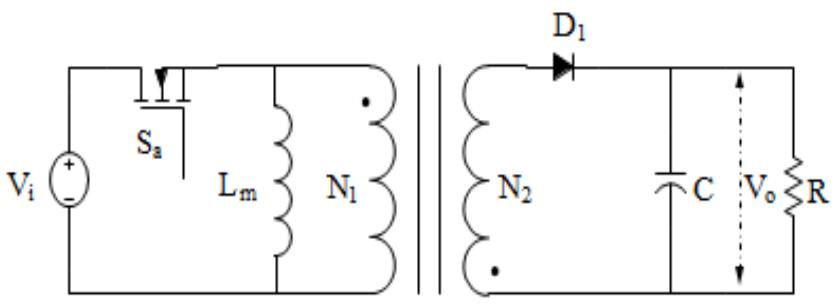

Fig 1:- Conventional Flyback converter [2]

During switch on condition the energy is incorporated into the primary winding and due to the dot convention of the transformer as shown in Fig. 1, the energy from the secondary winding does not get supplied to the load [3]. During this period, the output capacitor supplies the energy to the load. During turn OFF condition, no current flows in the transformer's primary. Simultaneously, the transformer's secondary voltage polarity changes. Therefore, the energy is carried from the transformer to the output. Thus, the operation of converter is determined by the dot-ends of the inductor [3]. The amount of output DC voltage depends on the on-time of the switch during a switching period. For longer on time of the switch, larger output DC voltage is obtained. The transformer must be reset to equalize the negative volt-seconds and positive volt-seconds. If this condition is not satisfied, then a large amount of energy will be stored in the transformer during a switching cycle [3]. Due to this, the net accumulation of energy causes the transformer saturation and also leads to the short circuit of primary resulting in the failure of the switch. 


\section{VARIOUS TYPES OF SNUBBERS}

\section{A. Tertiary winding method}

The tertiary winding method is commonly used as "reset" winding. This reset winding is tightly coupled to the primary winding, to minimize the leakage between the primary winding and the reset winding. This reset winding can take-up all the ampere-turns from the primary winding when the switch turns OFF [3].

\section{B. Resistor Capacitor and Diode(RCD) snubber}

Resistor Discharge Clamp(RCD) is one of the simplest snubber circuit consisting of a resistor, a capacitor and a diode. The problem of voltage stress can be solved by the traditional method called passive RCD [4]. The flyback converter with RCD snubber circuit is shown in Fig.2.

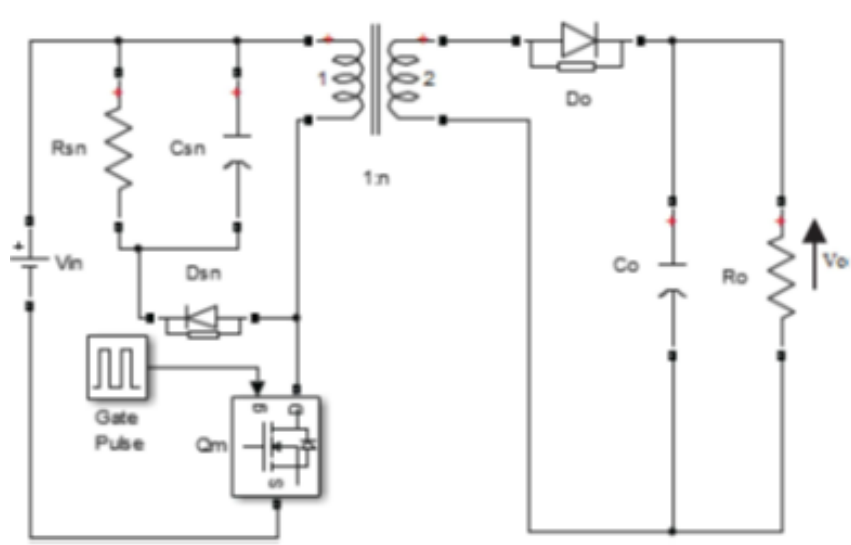

Fig 2:- Flyback converter with RCD snubber [5]

The flyback converter with the RCD snubber works as follows: During turn off, the transformer leakage current has two ways, the first one can be through the output capacitance of the switch and one more through the snubber circuit clamp capacitor $\left(\mathrm{C}_{\mathrm{sn}}\right)$.

In Flyback converter with RCD snubber, the rate of rise of voltage across the switch is slower since the net capacitance is larger resulting in lesser voltage across the switch [5].

\section{Energy regenerative snubber}

The most efficient snubbers are the ones that has an ability to regenerate the energy without dissipating it [6]. The converter works as follows: During the turn off condition of switch Smain, the energy to the snubber capacitor Cclamp is supplied from the leakage inductance through the diode D1. Gradually, the current through D1 and Cclamp decreased to zero. During the turn-on period of the switch, Cclamp discharges through the path that includes a switch, the diode Dreg, and the auxiliary winding. As the auxiliary winding $(\mathrm{Lm})$ is linked to the main transformer thus the energy in the Cclamp is accumulated in the transformer [6]. This stored energy is discharged to the output in addition to the energy that is usually stored in the flyback transformer during turn off condition [6].
A Flyback converter with energy regenerative snubber is shown in Fig.3.

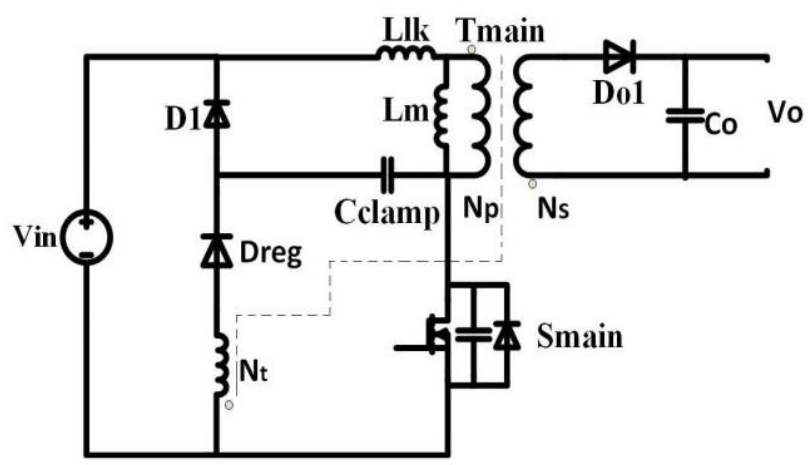

Fig 3:- Flyback converter with energy regenerative snubber [7].

$$
\begin{gathered}
V_{\mathrm{in}}=\left(L_{m}+L_{i k}\right) \frac{d i_{i m}}{d_{i}} \\
i_{i m}(t)=i_{i k k}(t) \frac{V_{i n}}{L_{1 n}+L_{i k}} t+i_{i m}\left(t_{0}\right)
\end{gathered}
$$

Where,

$$
\begin{aligned}
& V_{\text {in }} \text { : Input voltage; } \\
& \mathrm{L}_{\mathrm{m}} \text { : Magnetizing inductance; } \\
& \mathrm{L}_{\mathrm{ik}} \text { : Leakage inductance; }
\end{aligned}
$$

$\mathrm{I}_{\mathrm{Im}}(\mathrm{t})$ : Current through the magnetizing inductance at time $\mathrm{t}$; $\mathrm{i}_{\text {lik }}(\mathrm{t})$ : Current through the leakage inductance at time $\mathrm{t}$.

\section{Active clamp snubber}

An active clamp snubber is the one that consists of an active switch as shown in Fig. 4.

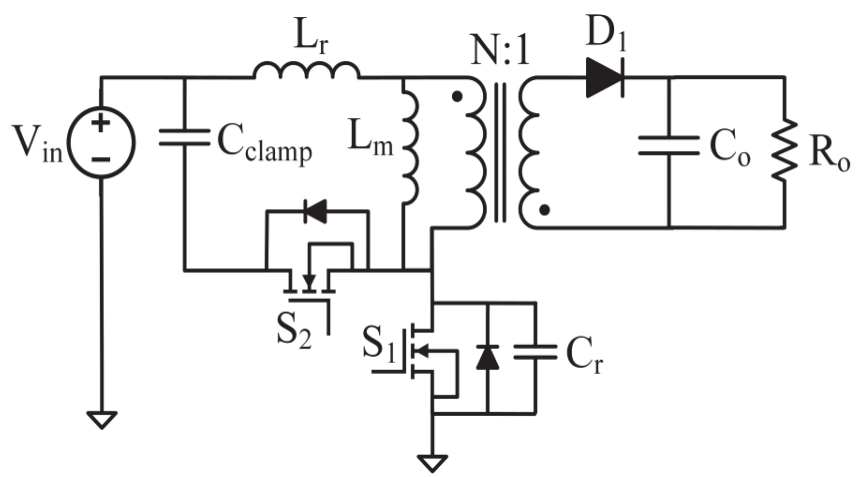

Fig. 4:- Flyback converter with active clamp snubber [8]

An auxiliary switch and a clamp capacitor are used to reduce the voltage stress of active switch in the flyback converter [9]. This active switch enables the snubber to work with zero-voltage switching (ZVS). Application of ZVS assures a vital reduction of switching losses due to the non-overlapping of voltage and current [10].

The flyback converter with active clamp snubber works as explained below: While the main switch S1 is made to turn off, the energy of the transformer leakage inductance $\mathrm{Lr}$ is carried to the snubber capacitor Cclamp by the body diode of S2[10When the current flows through its body diode, $\mathrm{S} 2$ can be turned on with ZVS [10]. In the 
following switching cycle, the S1 is turned on and S2 is turned off, then the current begins to flow through the body diode of S1, thus enabling switch S2 to turn on with ZVS.

\section{SIMULATION RESULTS}

Flyback converter with various snubbers are simulated using LTspice tool. The voltage stress across the MOSFET with different snubber circuits are compared and the results are discussed as below.

Table 1:

The designed values of Flyback converter are shown in

\begin{tabular}{|c|c|}
\hline Input voltage & $24 \mathrm{~V}$ \\
\hline Output voltage & $7 \mathrm{~V}$ \\
\hline Duty ratio & $40 \%$ \\
\hline Output power & $10 \mathrm{watt}$ \\
\hline Efficiency & $\geq 75 \%$ \\
\hline Turns ratio & 3.0 \\
\hline Switching frequency & $40 \mathrm{kHz}$ \\
\hline Primary winding inductance & $90 \mathrm{uH}$ \\
\hline Secondary winding inductance & $10 \mathrm{uH}$ \\
\hline Output Capacitance & $200 \mathrm{uF}$ \\
\hline Load & $8 \mathrm{ohm}$ \\
\hline
\end{tabular}

Table 1:- Designed Values of the Flyback Converter

Fig.5 to Fig. 12 presents the voltage stress across MOSFET of Flyback converter with tertiary winding, RCD snubber, energy regenerative snubber and active clamp snubber.

\section{- Tertiary winding method}

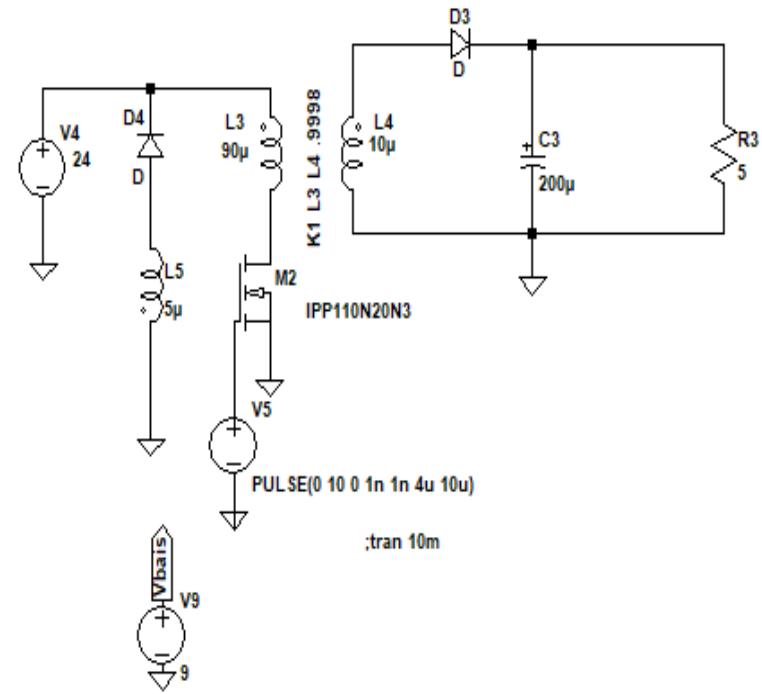

Fig 5:- Flyback converter with tertiary winding
Fig. 6 shows the voltage stress across the switch with tertiary winding method.

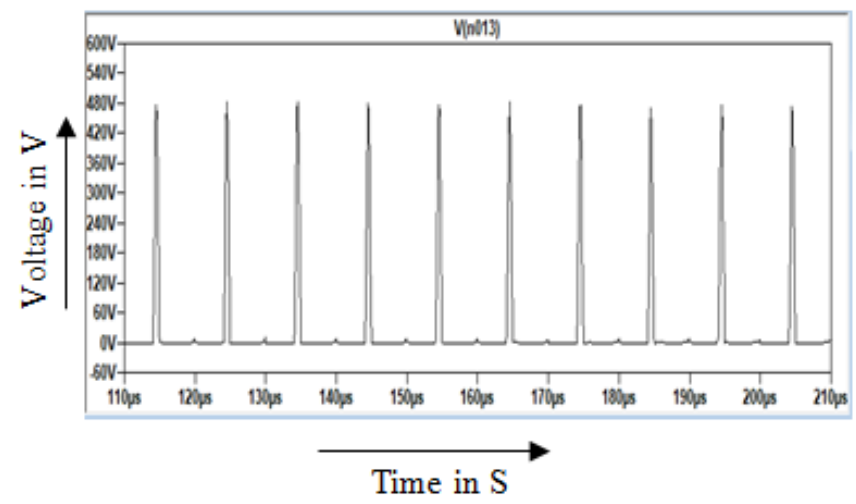

Fig 6:- Voltage stress across the switch with tertiary winding

It is observed that, with an input voltage of $24 \mathrm{~V}$, the voltage stress across the switch is $480 \mathrm{~V}$.

\section{RCD snubber}

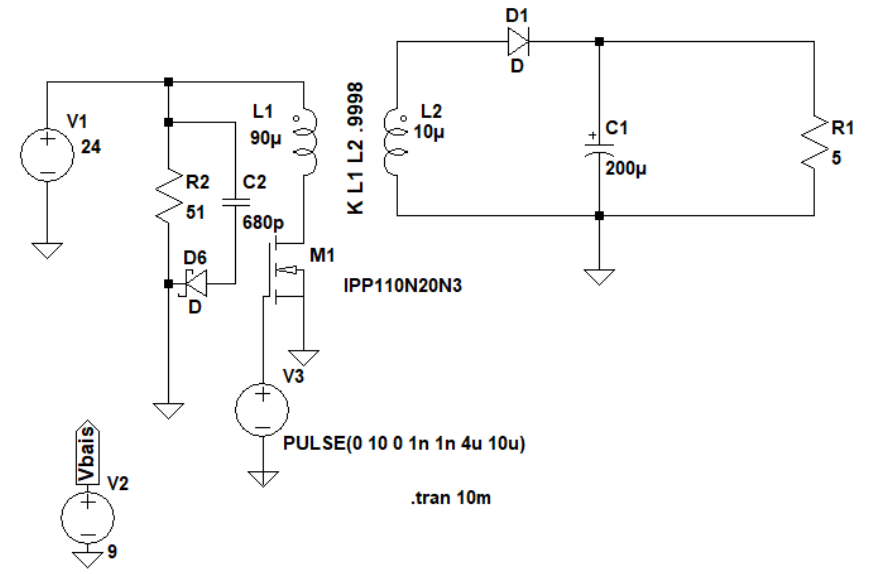

Fig 7:- Flyback converter with RCD snubber

Fig. 8 shows the voltage stress across the switch with a RCD snubber.

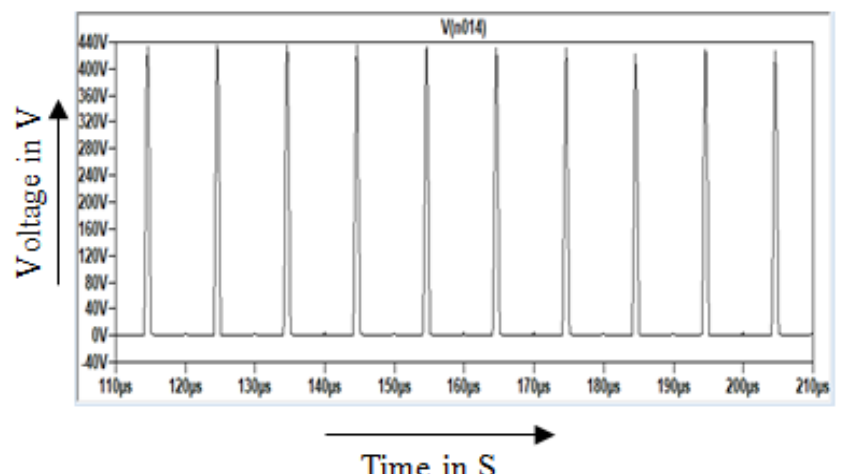

Fig 8:- Voltage stress across the switch with RCD snubber

It is observed that, with an input voltage of $24 \mathrm{~V}$, the voltage stress across the switch is $450 \mathrm{~V}$. 


\section{Energy regenerative snubber}

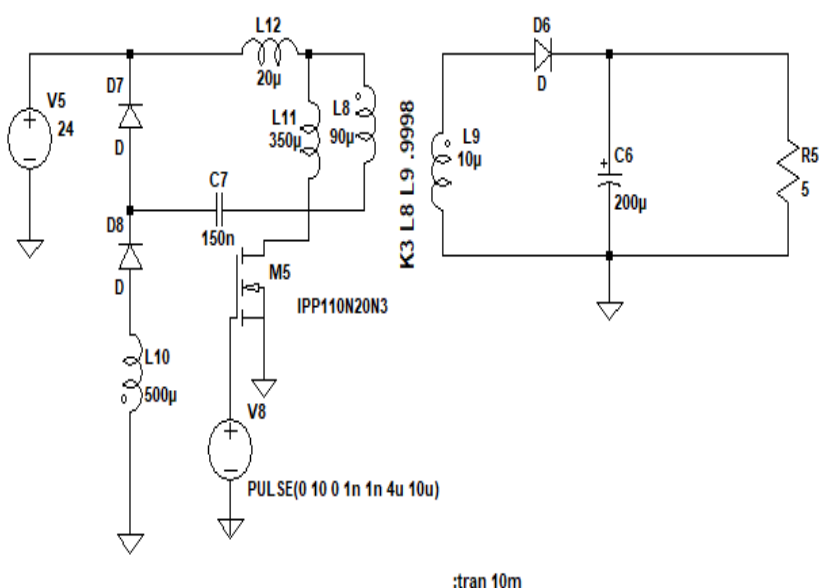

Fig 9:- Flyback converter with energy regenerative snubber

Fig. 10 shows the voltage stress across the switch with a energy regenerative snubber.

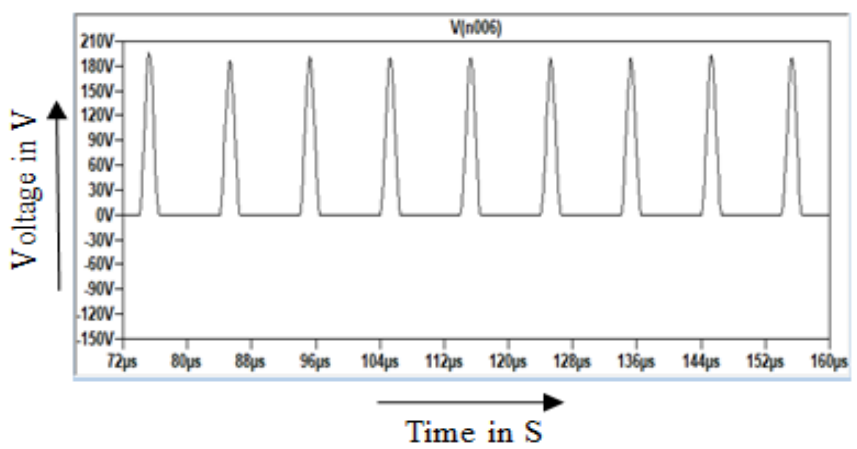

Fig 10:- Voltage stress across the switch with energy regenerative snubber.

It is observed that, with the input voltage of $24 \mathrm{~V}$, the voltage stress across the switch is $180 \mathrm{~V}$.

\section{Active clamp snubber}

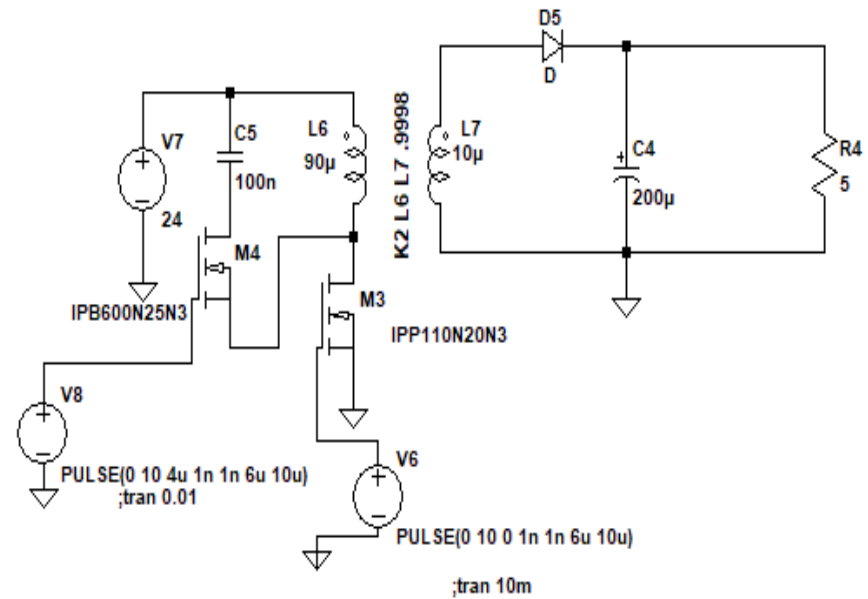

Fig 11:- Flyback converter with active clamp snubber
Fig. 12 shows the voltage stress across the switch with a active clamp snubber

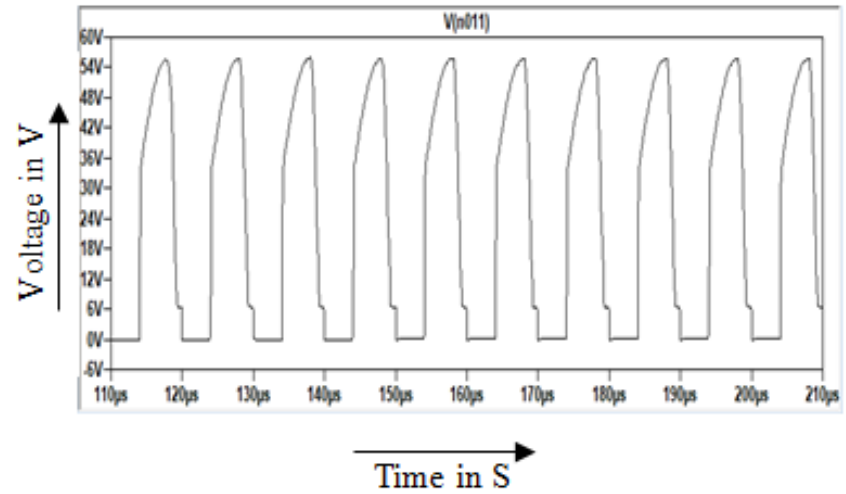

Fig 12:- Voltage stress across the switch with active clamp snubber.

It is observed that, with the input voltage of $24 \mathrm{~V}$, the voltage stress across the switch is $54 \mathrm{~V}$.

The input and output voltage for the Flyback converter with all the snubbers are common as specified in Table 1 and the same is shown in Fig.13.

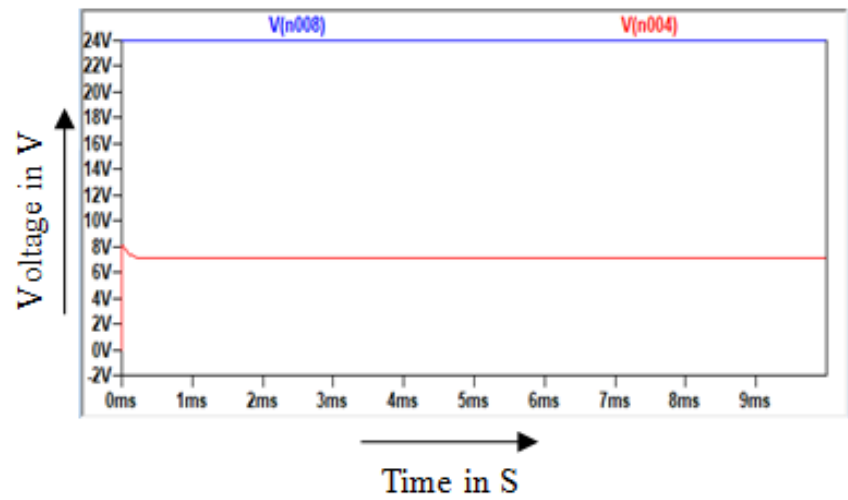

Fig 13:- Input and output voltage of Flyback converter with various snubber circuits.

It is observed that, with the input voltage of $24 \mathrm{~V}$, the output voltage with all the snubbers is observed to be constant at $7 \mathrm{~V}$.

The input voltage, output voltage and voltage stress across the switch with all snubbers are summarized in Table 2.

\begin{tabular}{|c|c|c|c|}
\hline & $\begin{array}{c}\text { Input } \\
\text { voltage }\end{array}$ & $\begin{array}{c}\text { Output } \\
\text { voltage }\end{array}$ & $\begin{array}{c}\text { Voltage } \\
\text { stress }\end{array}$ \\
\hline Tertiary winding method & $24 \mathrm{~V}$ & $7 \mathrm{~V}$ & $480 \mathrm{~V}$ \\
\hline RCD snubber & $24 \mathrm{~V}$ & $7 \mathrm{~V}$ & $440 \mathrm{~V}$ \\
\hline Energy regenerative snubber & $24 \mathrm{~V}$ & $7 \mathrm{~V}$ & $180 \mathrm{~V}$ \\
\hline Active clamp snubber & $24 \mathrm{~V}$ & $7 \mathrm{~V}$ & $54 \mathrm{~V}$ \\
\hline
\end{tabular}

Table 2:- Comparision of Voltage Stress with All Types of Snubbers 
It is observed from Table 2 that the voltage stress across the switch of a Flyback converter with active clamp snubber is less when compared with other types of snubbers.

\section{CONCLUSION}

In this work, the simulation results with different snubber circuits namely Tertiary winding method, RCD snubber, Energy regenerative snubber and Active clamp snubber are discussed for a Flyback converter.

The voltage stress across the MOSFET switch of the Flyback converter is compared with these different snubber circuits. It is observed from the simulation results that, active clamp snubber is found to be better compared with all other snubbers circuits considered in this work as the voltage stress across the MOSFET switch is found to be the least.

\section{ACKNOWLEDGEMENT}

Authors are grateful to the management, BMS Educational Trust, Principal and Vice-Principal, BMS college of Engineering for their valuable support.

\section{REFERENCES}

[1]. Daniel. W. Hart, "Power Electronics", The McGrawHill Company, $3^{\text {rd }}$ edition, 2010.

[2]. A. Boyar and E. Kabalci. (2018) "Comparison of a Two-Phase Interleaved Boost Converter and Flyback Converter," IEEE 18th International Power Electronics and Motion Control Conference, (pp. 352356).

[3]. N. Coruh, S. Urgun and T. Erfidan. (2010) "Design and implementation of flyback converters," 5th IEEE Conference on Industrial Electronics and Applications, (pp. 1189-1193).

[4]. H. Chung, S. Y. R. Hui and W. H. Wang. (1997) "An isolated fully soft-switched flyback converter with low voltage stress," PESC97. Record 28th Annual IEEE Power Electronics Specialists Conference. Formerly Power Conditioning Specialists Conference 1970-71. Power Processing and Electronic Specialists Conference, (pp. 1417-1423 vol.2)

[5]. R. Kanthimathi and J. Kamala. (2015) "Analysis of different flyback Converter topologies," International Conference on Industrial Instrumentation and Control , (pp. 1248-1252).

[6]. C. Liao, and K. Smedley. (2008) "Design of High Efficiency Flyback converter with energy regenerative snubber," Applied Power Electronics Conference and Exposition,( pp.796-800).

[7]. A. Alganidi and G. Moschopoulos. (2018) "A Comparative Study of Two Passive Regenerative Snubbers for Flyback Converters," IEEE International Symposium on Circuits and Systems , (pp. 1-4).
[8]. S. M. Tadvin, S. R. B. Shah and M. R. T. Hossain. (2018) "A Brief Review of Snubber Circuits for Flyback Converter,"3rd International Conference for Convergence in Technology, (pp.1-5).

[9]. Bor-Ren Lin, Kevin Huang and David Wang. (2006) "Analysis, design, and implementation of an active clamp forward converter with synchronous rectifier," in IEEE Transactions on Circuits and Systems vol. 53, no. 6,( pp. 1310-1319).

[10]. Y. Liu, B. Huang, C. Lin, K. A. Kim and H. Chiu. (2018) "Design and Implementation of a High Power Density Active-Clamped Flyback Converter," International Power Electronics Conference ( pp. 2092-2096). 